\title{
CENTRAL AND EASTERN EUROPE AFTER THE BOOM: TIME FOR A STRATEGY CHANGE FOR FOREIGN MULTINATIONAL COMPANIES?
}

\author{
Schuh, A.
}

This conceptual paper contributes to the discussion of the effects of the Great Recession on strategies of multinational companies operating in CEE. The author argues that the original business model that guided the "going East" of Western companies is still valid. However, foreign investors have adapted their strategies for CEE in the aftermath of the crisis: they differentiate stronger between the individual economies, follow a more cautious and selective investment approach, rationalize product portfolios, test new cost-efficient organizational arrangements and consider increasingly "value-for-money" strategies to tap the mass markets.

JEL classification: F23, M16

Keywords: Central and Eastern Europe; strategy; economic crisis; multinational company

\section{Introduction}

In 2008 the global financial and economic crisis ("Great Recession”) ended a six-year-long boom period with an average growth rate well above 5\% in Central and Eastern Europe (CEE). Although not being the cause of the crisis, some CEE countries such as the Baltic States and Ukraine were among the worst hit by this economic downturn. Not only did the crisis shatter the financial markets, banks and the real economy but also the growth image of CEE. It ended the notion that CEE will continue to grow faster than the West European economies for the next few years. The huge market potential and expected higher growth rates stemming from the catching-up process to West European standards have been the main reasons for the flood of foreign direct investments into the countries of the region in the two preceding decades. Suddenly, foreign direct investors were confronted with collapsing markets, shrinking disposable household income, business customers and partners on the verge of bankruptcy and no real sign of a quick recovery. While the situation improved a little in 2011, the economic outlook and the sentiment of foreign investors have remained gloomy, at least for parts of the region (Niessner, 2013). It is obvious that when faced with such a huge economic downturn companies stop geographic expansion and put the brakes on investments. This is mirrored in dramatic declines in foreign direct investment inflows into CEE countries by 35-85\% from their 2007-08 peaks in 2011 (UNCTAD, 2012). In addition to quick responses on the operative level such an unexpected and unprecedented external shock requires a comprehensive strategy review. Management has to question the validity of the key premises on which the strategy, in this case the expansion into CEE, was built and if these assumptions still fit the changed business environment.

The purpose of this paper is to contribute to the discussion of the effects of the Great Recession on strategies of Western multinational companies (MNC) operating in CEE. It centers on two aspects of strategy review: firstly, the reassessment of the underlying business model for CEE that guided Western investors in the past two decades and, secondly, the discussion of likely strategic and organizational responses of foreign multinationals to this massive crisis.

\section{Reassessing the business model for CEE}

The business model of foreign multinational companies that drove the expansion to CEE before 2008 was primarily based on the growth story. Tapping the huge market potential of a region of 20 countries with 330 million inhabitants was the most important motive to enter these reforming markets (Manea \& Pearce, 2004; 
Wes \& Lankes, 2001). Efficiency motives such as lower labor costs, lower taxes and generous subsidies by local governments as well as access to raw materials and cheap energy played a role too, especially in traditional and medium-technology industries such as automobiles, durable consumer goods, machinery, building materials or paper. These typical sought-after advantages when entering emerging or transitional markets have to be balanced against the higher risks associated with doing business in countries with poor infrastructure and a modern regulatory and legal framework in the making. Efforts by the Central and South-East European countries to join the European Union made foreign multinationals believe that the risk of doing business in CEE was lower than what they would typically attribute to a transition economy. They assumed the "EU umbrella" would mitigate the risk as the countries adhere to the political, legal and economic principles set by the EU. From a strategy perspective, a fast entry to enjoy first-mover advantages and a quick expansion in the region were the ingredients for success, particularly in those industries where broad market coverage and efficient local production bring important comparative advantages. In general, this outlined business model offered foreign multinationals higher returns on investment than in their (Western) home markets, at least until 2008.

How was this business model affected by the crisis? Interestingly, the outcome of this business model assessment is better than expected (Schuh, 2012a). The market potential, the main motivation to go to CEE, has not disappeared. We still find underdeveloped markets there in terms of consumption rates and product ownership and deficiencies in infrastructure. However, it will take longer for foreign multinationals to tap this market potential as the growth differential to Western Europe shrank. On the positive side, we can notice that the skilled labor workforce and the favorable resource situation were not eliminated by the crisis. Declining salaries, real estate prices, rents and prices for supplies in the formerly overheated economies have created an attractive cost base for businesses again. In countries with depreciating local currencies vis-à-vis the euro or dollar, this cost advantage is even enhanced. What really changed in the aftermath of the crisis is the risk perception of investors. Investment projects in CEE are now seen more realistically than in the boom time before 2008. Today, higher risk premiums are charged reflecting an adjusted view on associated country and business risks and higher costs of bank financing in general. As a consequence, the strategic approach turned from quick expansion and market penetration to a defensive and selective approach with a focus on the optimization of existing operations. After adjusting costs and capacity to the lower levels of demand and with the help of a gradual recovery in economic activity we should expect reasonable returns for CEE operations again. Summing up, the foreign multinationals might not regard this crisis as a total game changer (maybe with the exception of the banking industry) but rather as an interruption of the catching-up process which started with the economic transformation in the 1990s. This positive outcome of the assessment of the basic business model does not mean that no review of strategy, structure and organizational model is necessary. While the basic business model remains valid, foreign companies have responded to the crisis by reviewing and adapting their original internationalization strategies for the region.

\section{Strategy review for CEE}

Regional strategies such as a CEE strategy are reviewed on a global headquarters level as they are part of the overall global strategy of the MNC. A severe crisis such as this Great Recession can threaten the entire business and therefore needs, besides quick operative responses, a thorough and comprehensive discussion of the existing strategy and, if necessary, changes in strategy to remain profitable and stay competitive. Such a strategy review should address five decision areas that define the strategic orientation of the MNC in a region:

- Role of the region: What is the role of CEE within the global strategy? Is CEE seen as source of growth or rather as production location and supply source?

- Participation in CEE markets: Which are major markets and which are peripheral ones? Where is a strong presence needed? Where should the MNC pull out or reduce its commitment?

- Activity location: Which elements of the value chain should be located in the region?

- Product and marketing strategies: What are the right product and marketing strategies for CEE markets? Are these the same ones as in the pre-crisis times?

- Organizational model: What is the appropriate organization model for CEE now?

Any changes of regional strategy are reflected in these decisions. In sum, these decisions mirror the strategic orientation towards this group of countries. They are a statement about the commitment of the MNC to CEE (and specific countries) and how management sees the future corporate development in the region. While I acknowledge that it is difficult to generalize on the strategic moves due to variations in industry backgrounds, geographic presence, market positions and business 
performance of country operations, certain patterns can be identified in the response to the crisis. The following section gives a brief overview of the strategic moves of foreign MNCs operating in CEE based on actual decisions of by companies, published statements of executives, industry and company reports and surveys.

Starting with the role of CEE in the global strategy, the damage done by the crisis to the growth image of CEE is most evident, at least when compared to large emerging economies in Asia and Latin America and neighbor Turkey. Those benchmarks have outperformed in terms of economic growth most of the countries of the region in the last three years. Moreover, during the recession, the weaknesses in the business environment (e.g., excessive bureaucracy, prevalent corruption, weak court systems) have come to the fore and reminded the MNCs of the extra costs and risks of doing business in the region (EBRD, 2010). As a consequence, we can observe a more differentiated approach by MNCs toward the economies of the region as it is also mirrored in recent direct investment inflows and perceptions of executives (Ernst \& Young, 2012; UNCTAD, 2012). When grading countries by market potential, economic performance and institutional quality the following subgroups emerge (Schuh, 2012a):

- Central European countries such as Poland, Czech Republic, Slovakia, and Slovenia as well as Estonia with a high level of economic and institutional development have become role models for a successful economic transformation. They are all members of the EU and are well integrated into international value chains and have made a lot of progress in modernizing their economies;

- Russia and Ukraine are the largest markets of the region but they still have low purchasing power. Their economic development is highly dependent on energy and commodity exports and so far they have not succeeded in diversifying their economies. They are still lagging in the transition process from a command to a market economy and are plagued by exuberant bureaucracy, corruption and lack of transparency.

- South-Eastern Europe with two EU members Bulgaria and Romania - and then a group of relatively small countries on the West Balkan. The latter group is marked by a history of wars and ethnic conflicts that hinder necessary regional integration. In general, these countries are lagging behind Central European countries in economic development and are less attractive for foreign investors due to inefficient legal frameworks, poor infrastructure and smallness of many markets.

The crisis has definitely ended the perception of CEE as a homogeneous bloc ("Eastern bloc") shaped by its communist past. Foreign investors assess them now stronger by their own merits and their individual risk and opportunity profile than by their affiliation to a group of transitional economies with huge market potential. Summing up, CEE remains attractive as a market for West European MNCs given the higher growth rates and a still favorable cost position that makes them attractive for nearshoring. However, the CEE economies have lost in investment attractiveness relative to other emerging markets (Ernst \& Young, 2012).

In the course of the strategy review also the presence in CEE is under close scrutiny. In the boom time, a quick and broad presence in most of the CEE countries was important - the quality of the presence and the adequacy of market entry, namely if a country market is ripe for a company's products and services, was often not deeply considered. Being first to the market and outmaneuvering competitors became a strategic imperative. Especially, in acquisition-driven businesses such as fast moving consumer goods and financial retail services a patchwork of operations resulted over the years that often did not form a coherent CEE strategy. The crisis brought out the strengths and weaknesses of each country's operation and forced management to review and optimize their portfolio of regional activities. A continuing weak market position, unsatisfactory profitability and a deteriorating overall business climate in a country are typical triggers for a review. Local governments desperately looking for new income sources to reduce their budget deficits have turned from an investor-friendly attitude to a more confrontational style. Increasing discrimination against foreign firms in favor of domestic ones and the introduction of new "crisis taxes" specifically targeting foreign multinationals have tarnished the investment climate. It does not come as a surprise that foreign MNCs are rethinking their presence in particular markets when market volumes and sales decline, local units suffer losses and the business outlook remains unfavorable. Furthermore, retreat from CEE markets was often triggered by difficulties of the parent company in the home market where liquidity needs and capital requirements forced a sell-off of non-core businesses. In the last years, we have seen many examples of portfolio rationalization: ABInBev, one of the world's largest brewery groups, sold its breweries in nine CEE countries to a private equity firm but kept the very profitable operations in Russia and Ukraine in 2009; the French retailer Carrefour stopped 
its expansion plan to become the third largest retailer in Russia and exited Russia in 2010; Vattenfall, a leading European energy company with headquarters in Sweden, withdrew from Poland in 2011 to focus on its core markets in Sweden, Germany and the Netherlands. While there may be many reasons for the withdrawal from a CEE country, the fact itself indicates the relative role of CEE in the strategy hierarchy of the MNC.

This should not convey the impression that foreign direct investors have been leaving CEE in masses. The majority of direct investors have stayed in the region. In many cases you will not see a full retreat but a substantial reduction of the commitment to a country market by closing branches and cutting down the number of products and services actively offered. For instance, the leading bank in CEE, UniCredit Bank Austria, just announced the merger of its offices in the three Baltic States as well as in Czech Republic and Slovakia - they will run the business in the Baltics from Riga and the Slovak business from Prague in the future and turn the former national subsidiaries into branch offices.

While for newcomers a market entry in the aftermath of the crisis may be too risky, strongly established regional players may even take advantage of the ongoing industry restructuring. Given their insider knowledge of the market and business environment and superior financial strength, they exploit the weaknesses of smaller local and international competitors to improve their market share. Groupe Danone merged its Russian (and CIS) dairy unit with the Russian Unimilk to become the region's largest dairy company in 2010. Nectar, a Serbian beverage and jam producer, acquired the Slovenian competitor Fructal in 2011 whose parent needed the proceeds to reduce its debts. This deal helped Nectar to improve its market position in Western Europe and to enter the premium segment of fruit juices.

From 2004 to 2006, the new EU member states were among the most favored target countries for product relocations in the German manufacturing industry (Kinkel et al., 2009). As mentioned above, some CEE countries have even improved their cost position due to declining costs and currency devaluations. According to the "CEE-Barometer 2011" CEE strongly gained in attractiveness as a production location from 2009 to 2011 (Horvath \& Partners, 2011). It shows that CEE remains attractive as a location for manufacturing. Central European countries have undergone a massive "re-industrialization" after the fall of the Iron Curtain and betting on this sound industrial growth model has been paying off (Niessner, 2013). Foreign MNCs use CEE locations as an export platform to Western Europe and to serve regional markets. The well-developed industrial sector, particularly in Czech Republic, Slovakia, Slovenia and Hungary, which accounts for $30 \%$ of gross domestic product (compared to $19 \%$ in the euro-zone), has been an economic success story and is still attracting investments in industries such as cars and automotive components, household appliances, machinery, consumer electronics and paper. Romania and Serbia are trying to repeat this industrial growth model as the production of the low-price car Logan manufactured by Dacia-Renault and the joint venture of the Serbian government with Italian car maker Fiat to build the Fiat 500L in Kragujevac illustrate. The geographic closeness to West European markets, the availability of a skilled workforce at lower costs than in Germany, Italy, France or Scandinavia and the surging demand in CEE itself are driving the expansion of production capacity in CEE at the expense of their West European sister companies.

Another growth area in CEE is the outsourcing of IT and business process services by globally operating MNCs (Fifekova \& Hardy, 2010). From Minsk to Sofia service providers are mushrooming that gain from the trend among MNCs to move back-office activities such as accounting and order processing, and front-office activities such as customer service, to cheaper places. This applies also to higher-value IT services such as infrastructure support and custom software development. The availability of a well-educated workforce, good infrastructure, recognition of intellectual property rights, location in the same time zone and a perfect cultural fit with West European cultures are favoring CEE countries as so-called nearshoring locations. Due to the increased efficiency orientation in the aftermath of the crisis and the trend towards the establishment of shared service centers the export of business services is booming in CEE (Fifekova \& Hardy, 2010; Warsaw Business Journal, Poland's BOP boom, 28 January 2013).

Although the variety of products, market and competitive constellations makes it difficult to spot a clear trend in product and marketing strategies, it is evident that the recession has changed market structures and that "value-for-money" strategies are on the rise. The formerly pyramid-shaped market structure has shifted into a more bottom heavy pyramid. Upper-price segments, the domain of Western MNCs, have been losing volume to the lower price segments, the "bottom of the pyramid". Reduced salaries, increased unemployment and the dramatic indebtedness of many households markedly shrank the disposable incomes of consumers. Tight household budgets make them switch to cheaper alternatives such as promotional offers, private labels, 
local/regional products and self-grown produce. While consumer staples had been less affected, purchases of consumer durables and non-necessities declined dramatically. The Great Recession has led to a "forced rationalization” of consumer behavior in CEE. CEE households are looking increasingly for "good value for money" offerings. Discounters, private labels, strong local and regional producers and Asian low-price competitors benefit from this more price-sensitive consumer behavior. Western firms are not well prepared for this swing in demand. Their natural habitats are the top- and upper mid-tiers of the market where they position their well-known international brands with their comparative advantages in quality, performance, innovativeness and image. Nonetheless, Western MNCs cannot easily assume that the current market situation is a shortterm phenomenon and wait for the economic recovery to bring the consumers back to higher price levels. Fifty-six percent of the consumers, or 57 million people, in Eastern Europe are low-income consumers with less than \$10,000 income per year. In Russia and Ukraine, $70 \%$ of the population falls into this category (Pfeifer, Massen \& Bombka, 2007).

In the fast moving consumer goods sector, Groupe Danone and Henkel CEE have already successfully launched products to low-price segments. "Danone Gratka” in Poland and "Casa Buna” in Romania are examples of affordability strategies in the yogurt and dairy sector. Henkel CEE covers the low price segment in detergents with "Rex", a so-called economy brand that is distributed throughout the region. In multi-tier brand strategies the global brands are complemented by acquired or newly invented local or regional brands which target lower income segments and center on the affordability argument. When coming to the conclusion that this new market stratification is not a short-term phenomenon but rather a structural one, then Western MNCs have to figure out if they want to be present in this lower income segments and, if yes, how they can compete there in a profitable way. I am not contending that an entry into the price-sensitive mass market is the right decision for most Western MNCs but it should be worth serious consideration, particularly because you find increasingly similar polarized market structures in Western Europe too.

Finally, the organizational model for CEE has to be examined. In the boom period, we could observe a tendency towards decentralization. Given its success in building business and market share in the foreign markets, local management was granted greater autonomy in decision-making. This trend was promptly reversed when the crisis hit: the pendulum swung immediately back toward centralization. Headquarters wanted to have more control over investments, costs, liquidity and key accounts when sales took a significant dip and profitability was threatened. While the situation improved in the meantime, efficiency considerations are still dominating the management agenda. As a market recovery to pre-2009 levels didn't come as fast as many hoped for, management is concerned that costs will get out of control again. This is underlined by a 2012 survey of CEE headquarters of foreign multinationals located in Austria. The two most important forces shaping organizational decisions for CEE activities today are the pressure to reduce costs and the trend towards centralization in the corporate group (Schuh, 2012b). The study also shows that the discussion is less about the abolishment of CEE headquarters - they will continue to play a constructive role in regional management but more about rearrangements of decision-making processes and optimization of activities in the region. One major challenge is the smallness of many markets in CEE: local operations in South-Eastern Europe can hardly earn investments in these post-crisis times due to their subcritical sizes. It is only consequent when management began clustering neighboring markets with similar characteristics and introducing shared service centers for back-office activities. More cooperation between subsidiaries in regional clusters or the use of "patronage models" whereby a more developed neighboring subsidiary provides strategic guidance and managerial assistance to a smaller unit whose business is less developed are not only reducing costs but support best practices transfer too. As the strategy discussion is ongoing, we still have to wait to see the full impact on changes in the organizational structure. Given the huge differences in market development between the more advanced markets in Central Europe and the emerging markets in South-Eastern and Eastern Europe, MNCs have to postpone the introduction of standardized strategies and structures. Organizational structures for CEE have to match this need for differentiation and flexibility to be effective. The CEE organization in the making will finally resemble a regional network with dispersed roles (e.g., shared service center, center of functional/product excellence) among its national units that is orchestrated by regional or global headquarters.

\section{Conclusion}

This article contributes to the discussion of the effects of the Great Recession on strategies and organizational structures of foreign multinationals in CEE. It probably 
conveys a more optimistic picture of the region than many would expect. I tried to show that the business model for CEE that guided the expansion of foreign MNCs to CEE is still intact. The fact that investors are paying now more attention to country and business risk is a good sign - initial euphoria has given way to a more realistic assessment of opportunities and risks. A differentiated approach to the region is also part of this new realism. While an adaptation to the different country market situations will keep the MNCs effective, it comes with a cost, namely more complexity in managing the region (Grow East Congress, 2013). More problematic is the shattered growth image of CEE. My impression is that CEE has an image problem, particularly, when compared to Turkey and other large emerging economies. These benchmark economies are seen as more dynamic, less fragmented and with larger market potential. This comparative disadvantage is reflected in strategic reorientations of the MNCs towards Asia, Middle East and Latin America. Even so, the strong industrial base, the close integration into European and global value chains, expected further improvements of the business environment and a huge market potential right on the doorstep of West European MNCs are compelling arguments which cannot be easily overlooked. The small number of total withdrawals from CEE and the explicitly expressed commitment to the region by regional players such as Erste Bank or Raiffeisen International Bank tell us that the foreign MNCs still believe in CEE. All these mentioned efforts to stay competitive by exploring new strategies and organizational models may lead to the development of a regional economic space that is not only appreciated for high growth rates but also for its quality inputs and profitability.

\section{References}

EBRD (2010). Recovery and Reform - Transition

Report 2010. European Bank for Reconstruction and Development, (accessed December 20, 2012), [available at http://www.ebrd.com/pages/research/ publications/flagships/transition.shtml].

Ernst \& Young (2012). Growth, actually - European Attractiveness Survey 2012, (accessed February 18, 2013), [available at http://www.ey.com/GL/en/Issues/Businessenvironment/2012-European-attractiveness-survey\#].

Fifekova, M., Hardy, J. (2010). Business Service Foreign Direct Investment in Central and Eastern Europe trends, motives and impact. Project of the Economy and Society Trust and the University of Hertfordshire, UK. Project Paper, (accessed April 13, 2013), [available at http://www.czechinvest.org/data/files/ fdi-project-report-1981-cz.pdf]
Grow East Congress (2013). How to manage complexity in Central and Eastern Europe. $5^{\text {th }}$ Grow East Congress, May 16, Vienna, (accessed May 27, 2013), [available at http://www.wu.ac.at/cee/wissenstransfer/ grow_east/grow_east2013]

Horvath \& Partners (2011). CEE-Barometer 2011: Osteuropa - auf dem Weg zum zweiten Frühling? Studie - Ergebnisbericht, Mai 2011. Horvath \& Partners Management Consultants: Wien.

Kinkel, S., Maloca, S., Jäger, A. (2009). Produktions- und FuE-Verlagerungen ins Ausland: Verbreitung, Motive und strategische Implikationen für das deutsche Verarbeitende Gewerbe. Stuttgart: Fraunhofer IRB Verlag.

Manea, J., Pearce, R. (2004). Multinationals and transition - Business strategies, technology and transformation in central and eastern Europe. Houndmills: Palgrave Macmillan.

Niessner, B. (2013). Convergence 2.0. Erste Group Research - CEE Special Report, February 20, 2013, (accessed February 22, 2013), [available at http://www.erstegroup.com/de/ Presse/Presseaussendungen/Archiv/2013/2/20/ CEE-growth-drivers-intact].

Schuh, A. (2012a). Strategy Review for Central and Eastern Europe: Strategic Responses of Foreign Multinational Corporations to the Recent Economic and Financial Crisis, Journal of East-West Business, 18: 185-207.

Schuh, A. (2012b). The Current and Future Role of Regional Headquarters for Central \& Eastern Europe. Presentation at the 1. European Headquarters Congress, October 5, 2012, Vienna, (accessed February 17, 2013), [available at http://www.wu.ac.at/ cee/aktuelles].

UNCTAD (2012). World Investment Report 2012. UNCTAD Statistics, (accessed February 5, 2013), [available at http://unctad.org/en/Pages/Statistics/ About-UNCTAD-Statistics.aspx].

Wes, M., Lankes, H. P. (2001). FDI in economies in transition: M\&A versus Greenfield investment, Transnational Corporation, 10 (3): 113-129.

Author

Ass. Prof. Dr. Arnold Schuh Director - Competence Center for Central and Eastern Europe Vienna University of Economics and Business, Austria Augasse 2-6 1090 Vienna, Austria arnold.schuh@wu.ac.at 